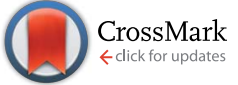

Cite this: Chem. Sci., 2016, 7, 3031

\title{
Chemoselective nitro reduction and hydroamination using a single iron catalyst $\uparrow$
}

\begin{abstract}
Kailong Zhu, Michael P. Shaver* and Stephen P. Thomas*
The reduction and reductive addition (formal hydroamination) of functionalised nitroarenes is reported using a simple and bench-stable iron(III) catalyst and silane. The reduction is chemoselective for nitro groups over an array of reactive functionalities (ketone, ester, amide, nitrile, sulfonyl and aryl halide). The high activity of this earth-abundant metal catalyst also facilitates a follow-on reaction in the reductive addition of nitroarenes to alkenes, giving efficient formal hydroamination of olefins under mild conditions. Both reactions offer significant improvements in catalytic activity and chemoselectivity and the utility of these catalysts in facilitating two challenging reactions supports an important mechanistic overlap.
\end{abstract}

Received 20th November 2015

Accepted 24th January 2016

DOI: $10.1039 / \mathrm{c} 5 \mathrm{sc} 04471 \mathrm{e}$

www.rsc.org/chemicalscience

they also showed excellent activity and chemoselectivity for the hydrosilylation of aldehydes and ketones over a wide range of other functionalities.

Inspired by this ability of the amine-bis(phenolate) catalyst to mediate both radical and reduction events we sought to extend this reaction manifold to the reduction and reductive functionalisation of nitroarenes. If the chemoselectivity and high catalyst activity observed in the carbonyl reductions could be transferred to nitroarene reductions, the amine-bis(phenolate) system would represent a clear advance of the current ironbased reduction manifolds. Moreover, if nitro reduction is combined with radical hydrogen-atom transfer (HAT) to an alkene, ${ }^{9}$ a formal hydroamination would be possible. As

gas alternative. ${ }^{4}$

Earth abundant metal catalysis is at the fore of academic and industrial research due to the inherent availability, sustainability, low cost and low toxicity of these metals. Iron holds a unique position, offering the lowest environmental and societal impact as it is the most abundant transition metal, nontoxic and environmentally benign. Although great strides have been made in the use of iron catalysts in organic synthesis, ${ }^{5}$ the reduction of nitro groups has received relatively little attention. ${ }^{6}$ The current state-of-the-art methods often require high catalyst loadings and long reaction times to transform a limited scope of substrates with low chemoselectivity.

We recently reported the reduction of carbonyl compounds using an iron(III)-amine-bis(phenolate) catalyst $\mathbf{4 b}$ and silane as the stoichiometric reductant (Scheme 1a). ${ }^{7}$ While these complexes were originally used as mediators of controlled radical polymerisations, ${ }^{8}$ (Scheme $1 \mathrm{~b}$ ) we were surprised that

School of Chemistry, University of Edinburgh, Joseph Black Building, David Brewster Road, Edinburgh, EH9 3FJ, UK. E-mail: michael.shaver@ed.ac.uk; stephen.thomas@ ed.ac.uk

$\dagger$ Electronic supplementary information (ESI) available. See DOI: $10.1039 / \mathrm{c} 5 \mathrm{sc} 04471 \mathrm{e}$ by Fe(III) amine-bis(phenolate) catalysts and the extension of these reactions to the reduction and reductive addition of nitroarenes.

a) Reduction of carbonyl compounds

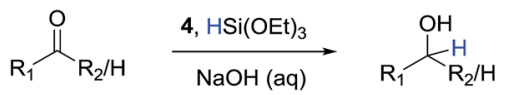

b) Radical polymerisation of styrene

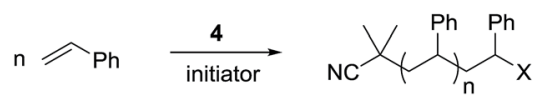

c) This work: reduction + radical addition

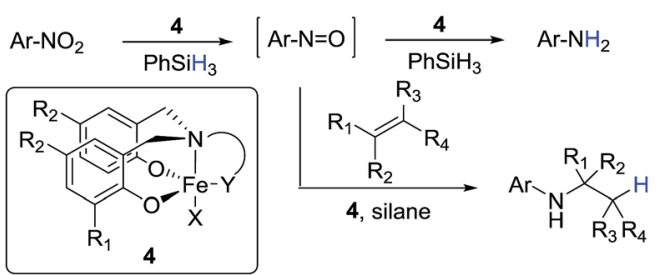

Scheme 1 Iron-catalysed reduction and radical reactions supported

\footnotetext{
reactions to the reduction and reductive addition of nitroarenes.
} 
recently reported, ${ }^{9}$ the iron-catalysed formal hydroamination of alkenes is an extremely powerful reaction accessible with high iron catalyst loadings ( $>30 \mathrm{~mol} \%)$ and elevated reaction temperatures $\left(60^{\circ} \mathrm{C}\right)$ to achieve moderate yields. We postulated that increasing the rate of nitroarene reduction, and thus increasing the concentration of the intermediate nitrosoarene, the overall efficiency of this process could be increased and the catalyst loading lowered significantly.

In the context of the catalytic flexibility of the Fe(III) aminebis(phenolate) framework, there is an obvious opportunity to develop a single catalytic system that is able to both reduce nitro compounds under mild conditions with high chemoselectivity and access a formal hydroamination of olefins at low catalyst loadings and temperatures (Scheme 1c).

\section{Results and discussion}

Our investigations began with the development of the chemoselective nitro reduction of 4-nitroacetophenone 1a (Table 1). Triethoxysilane was selected as the stoichiometric reductant due to its low cost, ease of handling and wide availability. ${ }^{10}$ Amine-bis(phenolate) iron(III) catalysts 4 a gave amine $2 \mathbf{a}$ in $79 \%$ yield with $7 \%$ reduction of the ketone to give alcohol 3a (entry 1). Catalyst $\mathbf{4 b}$, bearing the tetrahydro-2-furanyl

Table 1 Optimisation of reaction condition ${ }^{a}$

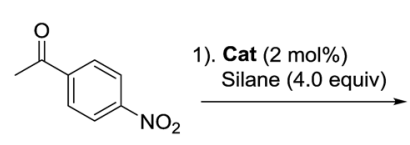

$1 a$

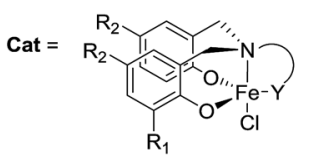

Furf = tetrahydro-2-furanyl

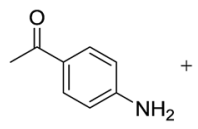

$2 a$

4a: $R_{1}=R_{2}=M e, Y=\left(\mathrm{CH}_{2}\right)_{2} \mathrm{NMe}_{2}$

4b: $R_{1}=R_{2}=M e, Y=C_{2}$ Furf

\begin{tabular}{lllllll}
\hline Entry & Cat. & Solvent & Silane & $\mathbf{S M}^{b}(\%)$ & $\mathbf{2 a}^{b}(\%)$ & $\mathbf{3 a}^{b}(\%)$ \\
\hline 1 & $\mathbf{4 a}$ & $\mathrm{MeCN}$ & $\mathrm{HSi}(\mathrm{OEt})_{3}$ & 7 & 79 & 7 \\
2 & $\mathbf{4 b}$ & $\mathrm{MeCN}$ & $\mathrm{HSi}(\mathrm{OEt})_{3}$ & Trace & $>95(91)^{c}$ & Trace \\
3 & $\mathbf{4 b}$ & $\mathrm{PhMe}$ & $\mathrm{HSi}(\mathrm{OEt})_{3}$ & 46 & 40 & 14 \\
4 & $\mathbf{4 b}$ & $\mathrm{THF}$ & $\mathrm{HSi}(\mathrm{OEt})_{3}$ & 84 & 14 & 2 \\
5 & $\mathbf{4 b}$ & $\mathrm{EtOAc}$ & $\mathrm{HSi}(\mathrm{OEt})_{3}$ & 51 & 35 & 14 \\
6 & $\mathbf{4 b}$ & $\mathrm{MeCN}$ & $\mathrm{PhSiH}_{3}$ & 22 & 60 & 11 \\
7 & $\mathbf{4 b}$ & $\mathrm{MeCN}$ & $\mathrm{Ph}_{2} \mathrm{SiH}_{2}$ & 55 & 26 & 10 \\
8 & $\mathbf{4 b}$ & $\mathrm{MeCN}$ & $\mathrm{Ph}_{2} \mathrm{MeSiH}$ & $>95$ & 0 & 0 \\
9 & $\mathbf{4 b}$ & $\mathrm{MeCN}$ & $\left.\mathrm{Me}_{3} \mathrm{SiO}\right)_{2} \mathrm{MeSiH}$ & $>95$ & 0 & 0 \\
$10^{d}$ & $\mathbf{4 b}$ & $\mathrm{MeCN}$ & $\left.\mathrm{HSi}_{(\mathrm{OEt}}\right)_{3}$ & Trace & $>95$ & Trace \\
$11^{e}$ & $\mathbf{4 b}$ & $\mathrm{MeCN}$ & $\mathrm{HSiMe}_{3}(\mathrm{OEt})_{2}$ & Trace & 90 & 5
\end{tabular}

${ }^{a}$ Unless otherwise noted, all reactions were carried out using 4.0 eq. of hydrosilane $(1.20 \mathrm{mmol}), 1.0 \mathrm{eq}$. of 4 -nitroacetophenone $(0.3 \mathrm{mmol})$, 0.02 eq. of catalyst $4(0.006 \mathrm{mmol})$ in $0.3 \mathrm{~mL}$ solvent at $80{ }^{\circ} \mathrm{C}$ for $4 \mathrm{~h}$. ${ }^{b}$ Determined by ${ }^{1} \mathrm{H}$ NMR using 1,3,5-trimethoxybenzene as internal standard. ${ }^{c}$ Isolated yield. ${ }^{d} 3.0$ eq. of triethoxysilane was used, $8 \mathrm{~h}$. $e^{e} 0.05$ eq. of catalyst was used. donating group gave both high reactivity and chemoselectivity for amine 2a (entry 2). Solvent had a significant influence on the reaction in terms of both reactivity and selectivity. Replacing MeCN with toluene gave a significant drop in both conversion and chemoselectivity (entry 3). Using THF gave an even lower conversion and reduction of the carbonyl group was observed (entry 4). Ethyl acetate gave a similar result to that of toluene with regard to conversion and selectivity (entry 5). The use of $\mathrm{PhSiH}_{3}$ or $\mathrm{Ph}_{2} \mathrm{SiH}_{2}$ as the reducing agent, significantly reduced conversion and chemoselectivity (entries 6 and 7). The sterically bulky silanes $\mathrm{Ph}_{2} \mathrm{MeSiH}$ and $\left(\mathrm{Me}_{3}-\right.$ $\mathrm{SiO})_{2} \mathrm{MeSiH}$ showed no reactivity towards either the nitro or carbonyl groups (entries 8 and 9). Reducing the amount of silane from 4.0 equivalents to 3.0 equivalents led to a longer reaction time of $8 \mathrm{~h}$ in order to obtain comparable reduction (entry 10). Using diethoxymethylsilane, a widely used surrogate for triethoxysilane with greater thermal stability, gave product $2 \mathrm{a}$ in $90 \%$ yield together with $5 \%$ of 3 a using $5 \mathrm{~mol} \%$ catalyst (entry 11).

The substrate scope of this newly developed catalytic system was investigated using the optimised reaction conditions of $2 \mathrm{~mol} \%$ catalyst $4 \mathbf{b}, 4.0$ equivalents of triethoxysilane in MeCN (1.0 M) at $80{ }^{\circ} \mathrm{C}$ (Table 2). In all cases, good to excellent yield and chemoselectivity were obtained, demonstrating the utility of this methodology in synthesis. Industrially important aniline could be prepared from nitrobenzene in $84 \%$ isolated yield (entry 1 ). $o$-Methyl, $m$ methyl and, in contrast to other methods, ${ }^{6}$ even the sterically hindered 2,6-dimethyl nitrobenzene were all successfully reduced in good yields (entries 2, 3 and 4). $p$-(Methylthio) aniline $2 \mathbf{f}$ was produced from the corresponding nitroarene in excellent yield, although an 8 hour reaction time was needed (entry 5 ). The selective reduction of the nitro group in the presence of an ester functionality proceeded smoothly in all cases with excellent yields (entries 6, 7, 8, and 9), indicating the complete chemoselectivity and reactivity of the developed system for these challenging substrates. ${ }^{\mathbf{1 1}}$ Methylsulfonyl substituted nitrobenzene $\mathbf{1 k}$ was also reduced with excellent chemoselectivity for the $\mathrm{NO}_{2}$ group (entry 10). In the case of 4-nitrobenzonitrile, 65\% yield of amine 21 was obtained; however, $30 \%$ of the starting material was recovered, once again demonstrating the high chemoselectivity of the catalyst for the nitro group over nitrile (entry 11). The low yield in the reaction of 4-nitrobenzonitrile is attributed to the strong coordination of the nitrile group to the catalyst which inhibits catalyst activity. To demonstrate this, a standard reduction of ethyl 4-nitrobenzoate was doped with 4-nitrobenzonitrile $(1: 1)$ and the yield of nitro reduction at ethyl 4nitrobenzoate $\mathbf{1 h}$ dropped from $98 \%$ to $30 \% .{ }^{12}$ Halogenated nitrobenzene derivatives were also reduced chemoselectively and in good yield without any protodehalogenation ${ }^{\mathbf{1 3}}$ or homocoupling ${ }^{14}$ observed (entries 12,13 and 14). Nitroarenes $\mathbf{1 p}$ and $\mathbf{1 q}$, bearing the strongly electron-withdrawing $\mathrm{CF}_{3}$ group, were reduced to the corresponding anilines, $2 \mathbf{p}$ and 2q, in $90 \%$ and $85 \%$ yield, respectively (entries 15 and 16). Nitro-substituted benzoxazole 1r was selectively reduced to corresponding amine $2 \mathbf{r}$ in $88 \%$ yield without any ring- 
Table 2 Substrate scope of nitroarene reduction ${ }^{a}$
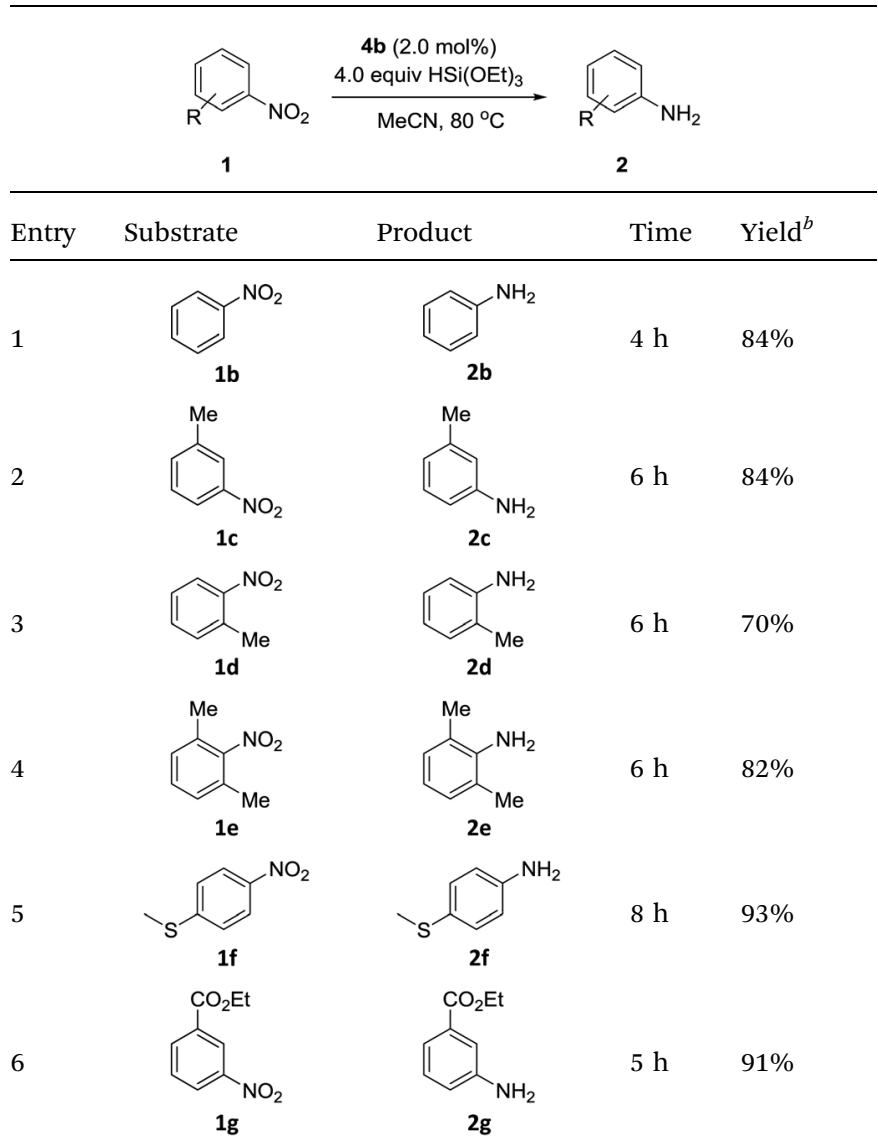

Product

Time Yield $^{b}$

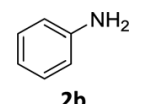

$4 \mathrm{~h}$

$84 \%$

2b<smiles>Cc1cccc(N)c1</smiles>

2c<smiles>Cc1ccccc1N</smiles>

2d<smiles>Cc1cccc(C)c1N</smiles>

$6 \mathrm{~h}$

$82 \%$<smiles>CSc1ccc(N)cc1</smiles>

$8 \mathrm{~h}$

$93 \%$<smiles>CCOC(=O)c1cccc(N)c1</smiles>

$5 \mathrm{~h}$

$91 \%$

$2 \mathrm{~g}$<smiles>CCOC(=O)c1ccc([N+](=O)[O-])cc1</smiles>

8<smiles>CC(=O)c1cccc([N+](=O)[O-])c1</smiles>

1i

9<smiles>COC(=O)c1ccc([N+](=O)[O-])cc1</smiles>

10<smiles>O=[N+]([O-])c1ccc(OS(=O)(=O)[O-])cc1</smiles>

1k

11<smiles>N#Cc1ccc([N+](=O)[O-])cc1</smiles>

12<smiles>O=[N+]([O-])c1ccc(F)cc1</smiles>

13<smiles>O=[N+]([O-])c1ccccc1Cl</smiles>

14

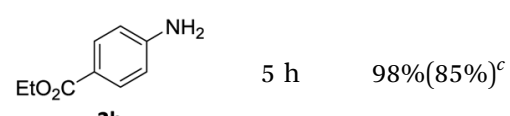

$5 \mathrm{~h}$

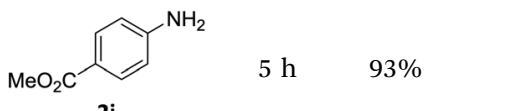

$4 \mathrm{~h}$

$6 \mathrm{~h}$

$5 \mathrm{~h}$

$8 \mathrm{~h}$

$5 \mathrm{~h}$
Table 2 (Contd.)

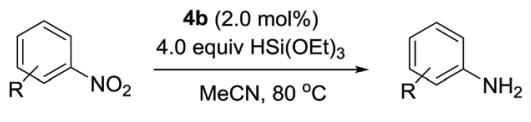

2

\begin{tabular}{|c|c|c|c|c|}
\hline Entry & Substrate & Product & Time & Yield $^{b}$ \\
\hline
\end{tabular}

15<smiles>O=[N+]([O-])c1cccc(C(F)(F)F)c1</smiles><smiles>Nc1cccc(C(F)(F)F)c1</smiles>

$90 \%$

16<smiles>O=[N+]([O-])c1ccc(C(F)(F)F)cc1</smiles><smiles>Nc1ccc(C(F)(F)F)cc1</smiles>

$3 \mathrm{~h}$

$85 \%$

$1 q$

17<smiles>CCc1nc2ccc([N+](=O)[O-])cc2o1</smiles><smiles>[Z7]c1nc2ccc(N)cc2o1</smiles>

$6 \mathrm{~h} \quad 88 \%$<smiles>Nc1cccc(C(=O)N2CCCCC2)c1</smiles>

$98 \%$

$18^{f}$<smiles>O=C(c1cccc([N+](=O)[O-])c1)N1CCOCC1</smiles>

1s

2s

19<smiles>[X]c1ccc([N+](=O)[O-])cc1</smiles>

$6 \mathrm{~h}$

$2 t$

${ }^{a}$ Unless otherwise noted, all reactions were carried out using 4.0 eq. of triethoxysilane $(2.40 \mathrm{mmol}), 1.0 \mathrm{eq}$. of nitro substrate $(0.6 \mathrm{mmol}), 0.02$ eq. of catalyst $(0.012 \mathrm{mmol})$ in $0.6 \mathrm{~mL} \mathrm{MeCN}$ at $80^{\circ} \mathrm{C}$. ${ }^{b}$ Isolated yield. ${ }^{c}$ Using 4.0 eq. of HSiMe(OEt) ${ }_{2}, 0.05$ eq. of $\mathbf{4 b}, 5 \mathrm{~h} .{ }^{d}$ Starting material recovered. ${ }^{e}$ Yield determined by ${ }^{1} \mathrm{H}$ NMR using 1,3,5trimethoxybenzene as internal standard. ${ }^{f} 0.04$ eq of catalyst was used.

opening or arene hydrogenation observed (entry 17). ${ }^{15}$ Nitrobenzene 1s, bearing an amide functionality, was also well tolerated to give the product in excellent yield (entry 18). When a substrate bearing a free alcohol was used, decreased catalytic activity was observed (entry 19).

To showcase the applicability of the developed nitro reduc$80 \%(15 \%)^{d} \quad$ tion, we explored the reduction of academically- and industrially-relevant targets. Bis(2-aminophenyl)amine $\mathbf{2 u}$, which is widely used in the synthesis of $N, N, N$-type pincer $^{16}$ or triamido ${ }^{17}$ $65 \%(30 \%)^{d} \quad$ ligands, was obtained in $80 \%$ isolated yield. This was directly comparable to the yield reported using palladium-catalysed reduction with $\mathrm{H}_{2} \cdot{ }^{16}$ Drug precursor $1 \mathbf{v}$ was chemoselectively reduced to amine $2 \mathbf{v}$ in $90 \%$ yield. This late stage reduction with a non-toxic metal greatly simplifies purification and trace metal removal, so making the developed method ideal for targets to be tested in vivo. ${ }^{18}$ Amidation of $2 \mathbf{v}$ would give 4-(pyrazole-1-yl) carboxanilides, a family of drugs that tune the activity of canonical transient receptor potential channels (TRPC) and thus control the influx of intracellular $\mathrm{Ca}^{2+}$ into a plethora of mammalian cell types (Scheme 2). ${ }^{\mathbf{1 9}}$

Having successfully developed a highly efficient silanemediated reduction of nitroarenes, we were keen to explore if 


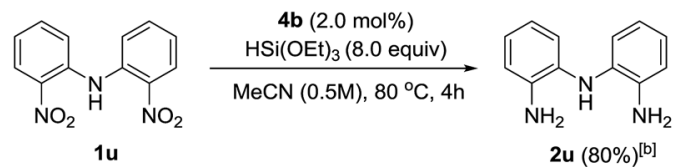

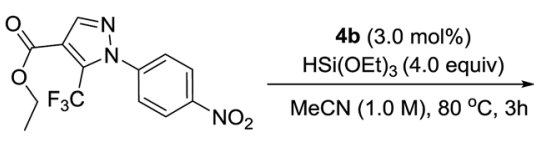

$1 \mathrm{v}$

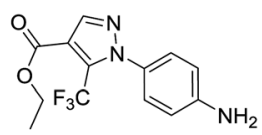

$2 v(90 \%)^{[b]}$
Scheme 2 Selective nitro reduction in the synthesis of 'real-world' targets. [a] Reactions were carried out using $0.6 \mathrm{mmol}$ of nitro compounds. [b] Isolated yield.

this could be combined with radical HAT for a formal hydroamination. ${ }^{9,20}$ We hypothesised that the high reactivity of $\mathbf{4 b}$ for nitroarene reduction would increased rates of reactions with alkenes. Strikingly, application of catalyst $\mathbf{4 b}$ in the formal hydroamination of alkenes using nitroarene $\mathbf{1 w}$ and alkene 5a gave amine $\mathbf{6 a}$ in $75 \%$ isolated yield after $\mathrm{Zn} / \mathrm{HCl}$ work-up ${ }^{21}$ using just $2.0 \mathrm{~mol} \%$ catalyst, a 15 -fold reduction in catalyst loading compared to the previous system. ${ }^{20}$ Additionally, the starting nitro substrate was fully consumed at room temperature in just $2 \mathrm{~h}$. 1-Chloro-2-nitrobenzene $1 \mathrm{n}$ gave the corresponding amine product $\mathbf{6 b}$ in relatively lower yield, potentially due to the halogenophilicity of the parent $\mathrm{Fe}$ complexes. ${ }^{8}$ A methyl substituted nitroarene 1c was well tolerated to give the formal hydroamination product $\mathbf{6 c}$ while nitroarene 1f, bearing a methyl thioester group, gave the corresponding amine $\mathbf{6 d}$, both in good yields. Nitroarene $\mathbf{1} \mathbf{x}$ with a free carbonyl group was also well tolerated to give the product 6e in lower yield but with the carbonyl functionality unchanged. Importantly, the formal hydroamination of olefin 5d could be further extended under the same reaction conditions. Reaction with 4-nitroanisole $\mathbf{1 y}$ followed by an intramolecular reductive amination gave the $\mathrm{N}$-arylpiperidine $7 \mathrm{a}$ in $45 \%$ yield, indicating the potential application of this method in the preparation of $N$-heterocycles (Scheme 3). Deprotection of the para-methoxyphenyl (PMP) group of 7a would give 2,2,6trimethyl piperidine which is a useful reagent for the $\alpha$-alkylation of aldehydes. ${ }^{22}$

\section{Conclusions}

We have developed a highly chemoselective, efficient and operationally simple amine-bis(phenolate) iron(III)-catalysed reduction of nitro compounds using triethoxysilane as the reducing agent. The system chemoselectively reduces aryl nitro groups over carbonyl, ester, imine, sulfonyl and cyano functionalities. The highly efficient formal hydroamination of alkenes has also been developed with excellent activity observed at room temperature with low iron catalyst loadings. Mechanistic studies and the investigation into the scope of catalyst $\mathbf{4 b}$ for reductive functionalisation continue.

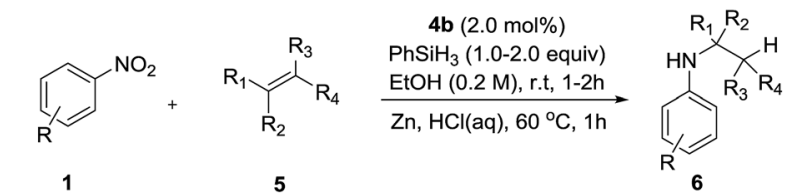

1w: $\mathrm{R}=4-\mathrm{C}$

1x: $R=4$-acetonyl

1y: $R=4-\mathrm{MeO}$

Olefins used in the formal hydroamination:
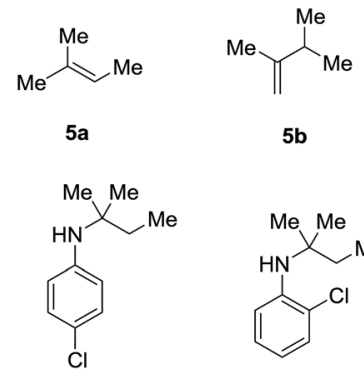<smiles>CC1=CCCCC1</smiles><smiles>CC(=O)CCC=C(C)C</smiles>

$6 a^{[b]}(5 a, 75 \%)$

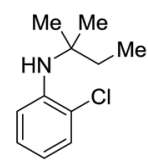

$\mathbf{6 b}^{[\mathrm{b}]}(5 \mathbf{a}, 46 \%)$
$5 c$

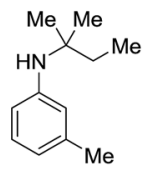

$6 c^{[b]}(5 b, 57 \%)$

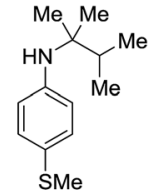

$\mathbf{6 d}^{[\mathrm{c}]}(\mathbf{5 b}, 60 \%)$

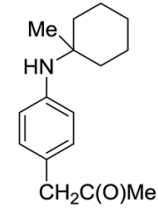

$6 \mathrm{e}^{[\mathrm{b}]}(5 \mathrm{c}, 40 \%)$

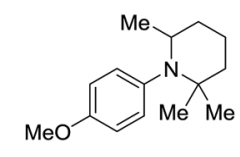

$7 a^{[c]}(5 d, 45 \%)$
Scheme 3 Formal hydroamination of olefins with catalyst 4b. [a] Reactions were carried out using $0.3 \mathrm{mmol}$ of nitro compounds and $0.9 \mathrm{mmol}$ of alkene. [b] 2.0 equiv. of silane, $2 \mathrm{~h}$. [c] 1.0 equiv. of silane, 1 h. Isolated yield are shown in parentheses together with the donor olefin used.

\section{Acknowledgements}

MPS and SPT thank the University of Edinburgh for Chancellor's Fellowships and the School of Chemistry for continued support. MPS thanks the Framework Program 7 for a Marie Curie Career Integration Grant. SPT thanks the Royal Society for a University Research Fellowship and a Research Grant. KZ thanks the China Scholarship Council and the University of Edinburgh for an academic scholarship. The authors thank Prof. Jason Love and AJ MacNair for useful discussions.

\section{Notes and references}

1 Transparency Market Research, Aniline Market-Global Industry analysis, Size, Share, Growth, Trends and Forecast 2014-2020.

2 R. S. Downing, P. J. Kunkeler and H. van Bekkum, Catal. Today, 1997, 37, 121-136.

3 B. Cornils and W. A. Herrmann, Applied Homogeneous Catalysis with Organometallic Compounds, Wiley-VCH, Weinheim, Germany, 2nd edn, 2002.

4 (a) I. Ojima, in The Chemistry of Organosilicon Compounds, ed. S. Patai and Z. Rapport, Wiley, New York, 1989; (b) M. A. Brook, in Silicon in Organic, Organometallic, and 
Polymer Chemistry, Wiley, New York, 2000; (c) Comprehensive Handbook on Hydrosilylation, ed. B. Marciniec, Pergamon, Oxford, 1992; (d) B. Marciniec, in Applied Homogeneous Catalysis with Organometallic Compounds, ed. B. Cornils and W. A. Herrmann, Wiley-VCH, Weinheim, 1996, vol. 1, ch. 2; (e) J. L. Speier, Adv. Organomet. Chem., 1979, 17, 407447; (f) B. Marciniec and J. Gulinski, J. Organomet. Chem., 1993, 446, 15-23.

5 For selected reviews, see: (a) K. Junge, K. Schröder and M. Beller, Chem. Commun., 2011, 47, 4849-4859; (b) B. A. F. Le Bailly and S. P. Thomas, RSC Adv., 2011, 1, 1435-1445; (c) C. Bolm, J. Legros, J. L. Paih and L. Zani, Chem. Rev., 2004, 104, 6217-6254; (d) M. D. Greenhalgh, A. S. Jones and S. P. Thomas, ChemCatChem, 2015, 7, 190222; (e) A. Correa, O. G. Mancheño and C. Bolm, Chem. Soc. Rev., 2008, 37, 1108-1117; (f) I. Bauer and H.-J. Knölker, Chem. Rev., 2015, 115, 3170-3387.

6 (a) Y. Sunada, H. Kawakami, T. Imaoka, Y. Motoyama and H. Nagashima, Angew. Chem., Int. Ed., 2009, 48, 9511-9514; (b) K. Junge, B. Wendt, N. Shaikh and M. Beller, Chem. Commun., 2010, 46, 1769-1771; (c) L. Pehlivan, E. Metay, S. Laval, W. Dayoub, P. Demonchaux, G. Mignani and M. Lemaire, Tetrahedron Lett., 2010, 51, 1939-1941; (d) L. Pehlivan, E. Metay, S. Laval, W. Dayoub, P. Demonchaux, G. Mignani and M. Lemaire, Tetrahedron, 2011, 67, 1971-1976.

7 K. Zhu, M. P. Shaver and S. P. Thomas, Eur. J. Org. Chem., 2015, 2119-2123.

8 (a) H. Schroeder, B. R. M. Lake, S. Demeshko, M. P. Shaver and M. Buback, Macromolecules, 2015, 48, 4329-4338; (b) L. E. N. Allan, J. P. MacDonald, A. M. Reckling, C. M. Kozak and M. P. Shaver, Macromol. Rapid Commun., 2012, 33, 414-418; (c) L. E. N. Allan, J. P. MacDonald, G. S. Nichol and M. P. Shaver, Macromolecules, 2014, 47, 1249-1257.

9 (a) J. Gui, C.-M. Pan, Y. Jin, T. Qin, J. C. Lo, B. J. Lee, S. H. Spergel, M. E. Mertzman, W. J. Pitts, T. E. L. Cruz, M. A. Schmidt, N. Darvatkar, S. R. Natarajan and P. S. Baran, Science, 2015, 348, 886-891; (b) M. Villa and A. J. v. Wangelin, Angew. Chem., Int. Ed., 2015, 54, 1190611908.

10 Triethoxysilane has been reported to form flammable gasses upon exposure to transition metal catalysts: (a) S. C. Berk and S. L. Buchwald, J. Org. Chem., 1992, 57, 3751-3753; (b) S. L. Buchwald, Chem. Eng. News, 1993, 71, 2; (c) S. L. Buchwald, U. S. Pat., 5220020, 1993.
11 (a) D. Bézier, G. T. Venkanna, L. C. M. Castro, J. Zheng, T. Roisnel, J.-B. Sortais and C. Darcel, Adv. Synth. Catal., 2012, 354, 1879-1884; (b) K. Junge, B. Wendt, S. Zhou and M. Beller, Eur. J. Org. Chem., 2013, 2061-2065; (c) H. Li, L. C. M. Castro, J. Zheng, T. Roisnel, V. Dorcet, J.-B. Sortais and C. Darcel, Angew. Chem., Int. Ed., 2013, 52, 8045-8049.

$12 \mathrm{See} \mathrm{ESI} \dagger$ for details.

13 W. M. Czaplik, S. Grupe, M. Mayer and A. Jacobi von Wangelin, Chem. Commun., 2010, 46, 6350-6352.

14 R. R. Chowdhury, A. K. Crane, C. Fowler, P. Kwong and C. M. Kozak, Chem. Commun., 2008, 94-96.

15 It has been reported that benzoxazoles were reduced exclusively into ring-opened products using $\mathrm{NaBH}_{4}$, see: A. J. MacNair, M.-M. Tran, J. E. Nelson, G. U. Sloan, A. Ironmonger and S. P. Thomas, Org. Biomol. Chem., 2014, 12, 5082-5088.

16 P. Ren, O. Vechorkin, K. von Allmen, R. Scopelliti and X. Hu, J. Am. Chem. Soc., 2011, 133, 7084-7095.

17 R. R. Schrock, J. Lee, L. C. Liang and W. M. Davis, Inorg. Chim. Acta, 1998, 270, 353-362.

18 European Medicines Agency, DOC. Ref. EMEA/CHMP/SWP/ 4446/2000.

19 (a) J. Abramowitz and L. Birnbaumer, FASEB J., 2008, 23, 297-328; (b) Y. Yonetoku, H. Kubota, Y. Miyazaki, Y. Okamoto, M. Funatsu, N. Yoshimura-Ishikawa, J. Ishikawa, T. Yoshino, M. Takeuchi and M. Ohta, Bioorg. Med. Chem., 2008, 16, 9457-9466; (c) S. Kyonaka, K. Kato, M. Nishida, K. Mio, T. Numaga, Y. Sawaguchi, T. Yoshida, M. Wakamori, E. Mori, T. Numata, M. Ishii, H. Takemoto, A. Ojida, K. Watanabe, A. Uemura, H. Kurose, T. Mori, T. Kobayashi, Y. Sato, C. Sato, I. Hamachi and Y. Mori, Proc. Natl. Acad. Sci. U. S. A., 2009, 106, 5400-5405; (d) D. Obermayer, T. N. Glasnov and C. O. Kappe, J. Org. Chem., 2011, 76, 6657-6669.

20 (a) T. J. Barker and D. L. Boger, J. Am. Chem. Soc., 2012, 134, 13588-13591; (b) E. K. Leggans, T. J. Barker, K. K. Duncan and D. L. Boger, Org. Lett., 2012, 14, 1428-1431.

$21 \mathrm{Zn} / \mathrm{HCl}$ was added to transfer the $\mathrm{N}, \mathrm{O}$-alkylated product into desired hydroamination product as it could not be reduced by silane under the reaction condition even at higher temperature. See ref. $9 a$ for the mechanism of the formation of the $\mathrm{N}, \mathrm{O}$-alkylated product.

22 D. M. Hodgson and N. S. Kaka, Angew. Chem., Int. Ed., 2008, 47, 9958-9960. 